\title{
The Influence of Humic Fertilizer on Morphological and Physiological Properties of Soybean Crop, in The Conditions of the Moldavian Plateau
}

\author{
Daniel Costel GALEŞ ${ }^{1^{*}}$, Gerard JITĂREANU ${ }^{1}$ \\ ${ }^{1}$ Department of Pedotechnic, University of Agricultural Sciences and Veterinary Medicine of Iasi, Mihail \\ Sadoveanu Alley, no. 3, 700490 Iasi, România. \\ * corresponding author: galesdan@yahoo.com
}

Bulletin USAMV series Agriculture 72(1)/2015

Print ISSN 1843-5246; Electronic ISSN 1843-5386

DOI 10.15835/buasvmcn-agr: 10425

\begin{abstract}
In this study we analyzed the influence of a humic fertilizer (Lignohumate) on some morphological and physiological characteristics of soybean plants. Lignohumate has a high humic acid content, and around $20 \%$ of its weight it's represented by sodium and potassium. The study was conducted between 2010-2012, in the climatic conditions of the Moldavian Plateau (Ezăreni Farm, Iasi, $47^{\circ} 5^{\prime}-47^{\circ} 10^{\prime} \mathrm{N}$ latitude, $27^{\circ} 28^{\prime}-27^{\circ} 33^{\prime} \mathrm{E}$ longitude), on a terrain with $3-4 \%$ slope, cambic chernozem with clay loam texture, having medium to good fertility (medium stock of nitrogen and phosphorus and good stock of potassium), slightly acidic $\mathrm{pH}$ and a humus content of about 2.5-3.0\%. There were applied four treatments, one on seeds and three on vegetation (2-3 leafs stage, before and after flowering). The leaf chlorophyll content, average number of pods per plant, number of plants per hectare and average plant height were determined. The average results of the experimental years have shown a positive influence of the humic fertilizer on the parameters we analyzed, the differences compared to the control being statistically assured. The treated plants had the average height with $3.7 \mathrm{~cm}$ higher, 2.2 more pods, and the chlorophyll content had values with $1.7 \mathrm{CCI}$ higher compared to the untreated control.
\end{abstract}

Keywords: lignohumate, humic fertilizer, soybean, morphological properties.

\section{INTRODUCTION}

Humic substances (from the Latin word 'humus' which means earth, soil), were discovered in 1786 by the German researcher F. Arhard, and over 200 years were worldwide researched and implemented by the scientists Tugarinov et al., (2010). In the last half of century a substantial contribution to the study of humic substances was bought by the researchers Eyheraguibel et al. (2008), Klučáková et al., (2006, 2005, 2004, 2003, 2002, 2000).

Humic substances are obtained by physical and chemical degradation of the homogenous lignocellulosic material Eyheraguibel et al., (2008), Morard et al., (2005). An important role in this process is played by the soil microbiota (Stefan, 2008).

They have an increased content of organic carbon (9.36 g C / l), containing 56.4\% humic acid and a high level of fulvic acid (43.6\%) Chen et al., (1977).

Humic substances (humates) are extensively used in agriculture. Humates are important due to their chemical properties of biopolymers such as: high exchange capacity for cations and anions; chelating capacity; ability to improve the functions of plant protection, growth and development; the ability to interact with soil yeast, vitamins and other substances. 
These circumstances led to the active development of the market offers for the concentrated humic substances as organic fertilizers and also of their use for the development of mineral fertilizers.

Almost all life in the soil is dependent on organic matter for nutrients and energy. People have long recognized the importance of organic matter for plant growth. Although organic matter in soils is very beneficial, Justus von Liebig, a famous German chemist, pointed out about 150 years ago that soils composed entirely of organic matter are naturally infertile Forth and Turk (1972) cited by Topa et al., (2013).

The aim of the research is to introduce in the crop technology of soybean a humic fertilizer known as Lignohumate. We also aimed to quantify the positive and negative influences of its use on some morphological and physiological elements of the soybean plants.

\section{MATERIALS AND METHODS}

The research was conducted in the climatic conditions of the Moldavian Plateau (Romania) in the Didactic Station of the "Ion Ionescu de la Brad" University of Agricultural Sciences and Veterinary Medicine from Iasi, Ezăreni Farm. The experiment was located on a slope of 3-4\%, clay loam cambic chernozem soil, formed on loess, with medium to good fertility (with medium content of $\mathrm{N}$ and $\mathrm{P}_{2} \mathrm{O}$

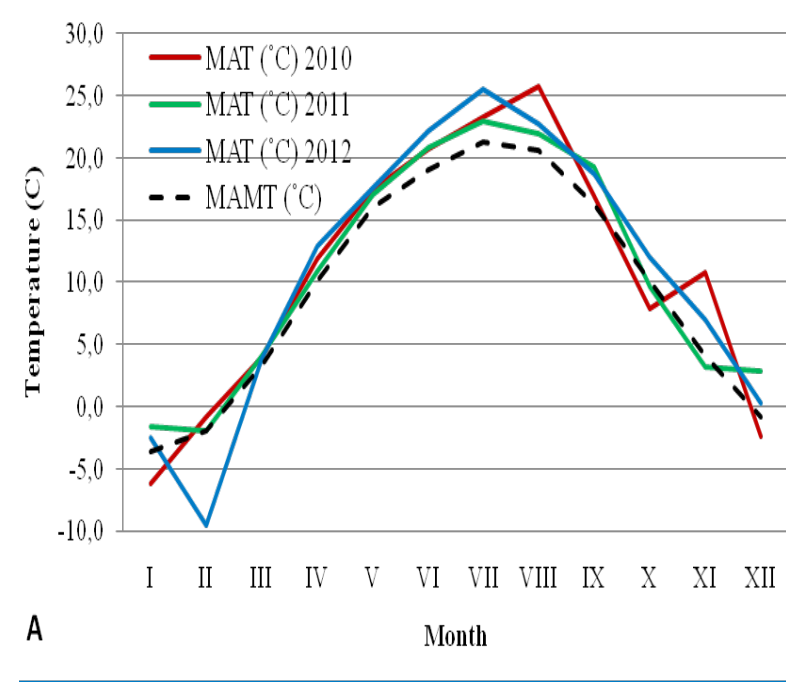

MAT - Multi-annual temperature MAMT - Multi-annual mean temperature and higher content of $\mathrm{K}_{2} \mathrm{O}$ ), soil pH weakly acidic and humus content of about 2.5 to $3.0 \%$.

The climatic conditions of the analyzed period of time are shown in (Fig. 1) (A - temperature, Brainfall).

The crop technology was the specific one for soybean. The fertilizers were applied with a dose of $60 \mathrm{~kg} / \mathrm{ha} \mathrm{P}_{2} \mathrm{O}_{5}$ a.s. $+60 \mathrm{~kg} /$ ha $\mathrm{N}$ a.s., before seedbed preparation.

The seedbed was prepared on the day of sowing, using the kompaktor cultivator and the sowing was done with SPC6 + U650. We used the Pioneer hybrids, known as PR91M10.

Soybean was sown when the soil temperature reached a minimum of $7-8^{\circ} \mathrm{C}$, corresponding to the daily average temperature of $14-15^{\circ} \mathrm{C}$, using an amount of $90 \mathrm{~kg} / \mathrm{ha}$. The sowing was carried out in strips of three lines at $45 \mathrm{~cm}$, with $60 \mathrm{~cm}$ between them, and the depth was between 4 and $5 \mathrm{~cm}$.

Along with the agro-technical measures for weed control, there were used chemicals, such as Dual Gold 960 EC (1.0 L/ha) in a pre-emergence treatment against annual monocotyledon weeds and some dicotyledons (Setaria sp., Echinochloa sp., Digitaria sp., Amaranthus sp., Chenopodium $s p$., Hibiscus sp.). Basagran has been used postemergence (2 L/ha).

The seeds were treated with $100 \mathrm{~g}$ Lignohumate in $10 \mathrm{~L}$ of water/t of seeds.

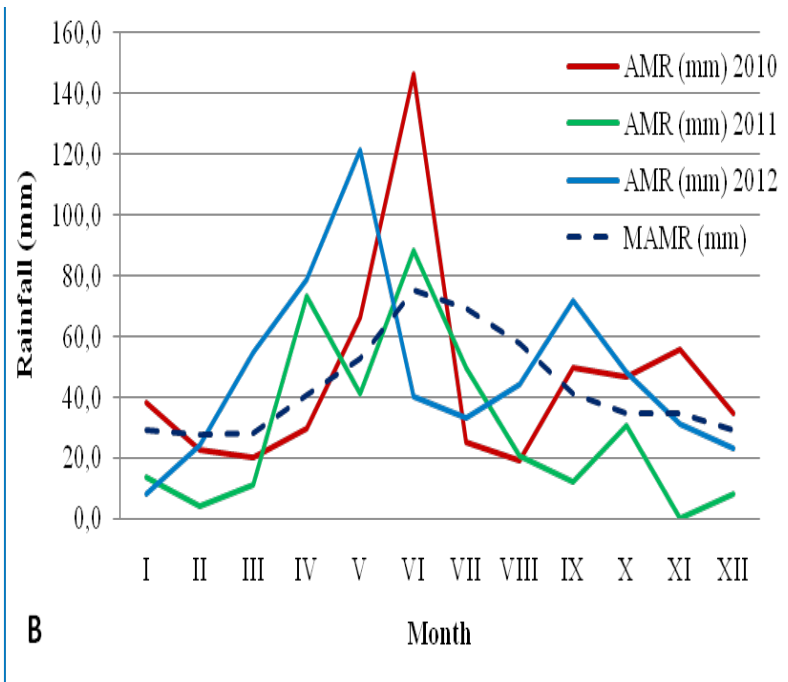

AMR - Average monthly rainfall MAMR - Multi-annual mean rainfall

Fig. 1. Characterization of climatic factors for 2010-2012

( $A$ - air temperature, $B$ - rainfall) 


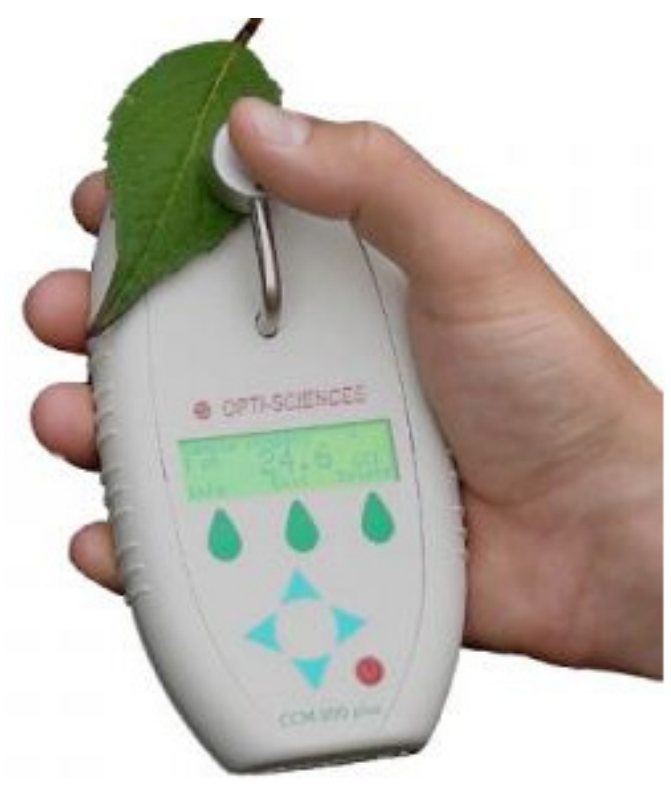

Fig.2 Device used for determining the chlorophyll content of leaves (http://www.envcoglobal.com)

During vegetation there were made three foliar treatments, in the 2-3 leaves stage, before and after flowering, using a dose of $60 \mathrm{~g} / \mathrm{ha} / 300 \mathrm{~L}$ of water for each treatment.

It was determined the average number of pods per plant, average plant height, average number of plants per ha and the chlorophyll content.

In order to determine the average plant height, there were made measurements using the tape line at 30 days after sowing, before and after flowering and at harvesting.

The average number of plants per ha was determined at harvesting, when were counted the plants from a $\mathrm{m}^{2}$, in 6 repetitions and reported to the area of an ha.

The chlorophyll content in leaves was measured using the CCM 200 plus device from Opti-Science Company (Fig. 2). It is a tool for measurements performed in the experimental field and makes precise, reliable and easy chlorophyll content determination of leaves. The device can store 4000 measurements performed with a detector with two photo-diodes with absorbance amplifier.

The measurements were made at approximately 30 days after sowing in early July and late July. Determinations were made in the upper third of the plants, in the middle thereof and in the lower third, in order to highlight more clearly the way in which the plant growth is influenced by the Lignohumate treatments. The device records the data in the internal memory, which are then downloaded to the $\mathrm{PC}$, where they were processed using the ANOVA and the F test.

\section{RESULTS AND DISCUTIONS}

Determining the average number of pods per plant

The Lignohumate treatments influenced the number of pods per plant. Between fertilized and control variant there were recorded statistically significant differences in 2010 and 2011, when water stress did not prevent the Lignohumate uptake. Years 2010 and 2011 were relatively similar in terms of climate, so that the differences between fertilized and control variants followed the same trend. In 2010 the difference was 3.1 pods/plant, and in 20113.0 pods/plant, given that the control variant registered 22.8 pods/plant in 2010 and 22.0 pods/plant in 2011 (Tab. 1).

In conditions less favorable for soybean crop recorded in 2012, the difference between fertilized and control variant was only 0.5 pods/plant, this difference not being statistically assured.

The statistical analysis of average values for the three years analyzed shows that the Lignohumate positively influenced the average number of pods per plant, the difference between fertilized and control variant recorded being significant. For the control variant the plants recorded an average number of 21.5 pods/plant, and for the treated variant 23.7 pods/plant (Tab. 1).

Determining the number of plants per hectare

The differences between fertilized and control variant in terms of number of plants per hectare were not statistically assured. They varied depending on climatic conditions between 1.66 thousand plants/ha in 2010 and 6.84 thousand plants/ ha in 2012 (Tab. 2).

It may be noted that under the conditions of 2012, considered unfavorable for the soybean crop, it was registered the highest difference between the control and fertilized variants.

This difference can be justified by the Lignohumate ability to reduce stress in plants, because the year 2012 is characterized by a water stress, especially in the second half, so we could say that the difference between the control and the treated variant varied with the soybean plants stress.

The statistical analysis of the mean values obtained in the three experimental years shows 
that the difference between the treated variant and the control was not statistically assured, and had a value of 4.16 thousand plants/ha. For the control variant the number of plants/ha was 274.17 thousand (Tab. 2).

Determining the average plant height

Tab. 1. The influence of Lignohumate on the number of pods per plant in soybean crop

\begin{tabular}{|c|c|c|c|c|c|}
\hline \multirow[b]{2}{*}{ Year } & \multirow[b]{2}{*}{ Variant } & \multicolumn{2}{|c|}{ Pods/plant } & \multirow[b]{2}{*}{$\begin{array}{l}\text { Difference } \\
\text { (no. of pods) }\end{array}$} & \multirow[b]{2}{*}{ Significance } \\
\hline & & $\begin{array}{c}\text { Pods / } \\
\text { plant }\end{array}$ & $\begin{array}{c}\% \text { compared to } \\
\text { control }\end{array}$ & & \\
\hline \multirow{3}{*}{2010} & $\mathrm{~V}_{1}$ - Control (untreated) & 22.8 & 100.0 & 0.00 & Control \\
\hline & $\mathrm{V}_{2}$ - Lignohumate ${ }^{*}$ & 25.9 & 113.6 & 3.10 & $\mathrm{x}$ \\
\hline & LSD $5 \%=2.2 \mathrm{pods} / \mathrm{pl}$ & \multicolumn{2}{|c|}{ LSD $1 \%=3.5$ pods $/ \mathrm{pl}$} & \multicolumn{2}{|c|}{ LSD $0.1 \%=6.0 \mathrm{pods} / \mathrm{pl}$} \\
\hline \multirow{3}{*}{2011} & $\mathrm{~V}_{1}$ - Control (untreated) & 22.0 & 100.0 & 0.00 & Control \\
\hline & $\mathrm{V}_{2}-$ Lignohumate $^{*}$ & 25.0 & 113.6 & 3.00 & $\mathrm{x}$ \\
\hline & LSD $5 \%=2.2$ pods $/ \mathrm{pl}$ & \multicolumn{2}{|c|}{ LSD $1 \%=3.5 \mathrm{pods} / \mathrm{pl}$} & \multicolumn{2}{|c|}{ LSD $0.1 \%=6.0 \mathrm{pods} / \mathrm{pl}$} \\
\hline \multirow{3}{*}{2012} & $\mathrm{~V}_{1}$ - Control (untreated) & 19.8 & 100.0 & 0.00 & Control \\
\hline & $\mathrm{V}_{2}$ - Lignohumate ${ }^{*}$ & 20.3 & 102.5 & 0.50 & \\
\hline & LSD $5 \%=3.6$ pods $/ p l$ & \multicolumn{2}{|c|}{ LSD $1 \%=5.7$ pods $/ \mathrm{pl}$} & \multicolumn{2}{|c|}{ LSD $0.1 \%=9.7 \mathrm{pods} / \mathrm{pl}$} \\
\hline \multirow{3}{*}{$\begin{array}{c}\text { Average } \\
2010- \\
2012\end{array}$} & $\mathrm{~V}_{1}$ - Control (untreated) & 21.5 & 100.0 & 0.00 & Control \\
\hline & $\mathrm{V}_{2}-$ Lignohumate $^{*}$ & 23.7 & 110.2 & 2.20 & $\mathrm{x}$ \\
\hline & LSD $5 \%=1.7 \mathrm{pods} / \mathrm{pl}$ & \multicolumn{2}{|c|}{ LSD $1 \%=2.6$ pods $/ \mathrm{pl}$} & \multicolumn{2}{|c|}{ LSD $0.1 \%=4.4$ pods $/ \mathrm{pl}$} \\
\hline
\end{tabular}

Tab. 2. The influence of Lignohumate on the number of plants per hectare on soybean

\begin{tabular}{|c|c|c|c|c|c|}
\hline \multirow[b]{2}{*}{ Year } & \multirow[b]{2}{*}{ Variant } & \multicolumn{2}{|c|}{ No. of plants } & \multirow{2}{*}{$\begin{array}{c}\text { Difference } \\
\text { (thousand } \\
\text { pl) }\end{array}$} & \multirow[b]{2}{*}{ Significance } \\
\hline & & $\begin{array}{c}\text { Thousand } \\
\text { pl/ha }\end{array}$ & $\begin{array}{l}\% \text { compared } \\
\text { to control }\end{array}$ & & \\
\hline \multirow{3}{*}{2010} & $\mathrm{~V}_{1}$ - Control (untreated) & 302.67 & 100.00 & 0.00 & Control \\
\hline & $\mathrm{V}_{2}-$ Lignohumate $^{*}$ & 304.33 & 100.55 & 1.66 & \\
\hline & $\begin{array}{c}\text { LSD } 5 \%=31.6 \text { thousand } \\
\text { pl } / \text { ha }\end{array}$ & \multicolumn{2}{|c|}{$\begin{array}{c}\text { LSD } 1 \%=49.6 \text { thousand } \\
\text { pl } / \text { ha }\end{array}$} & \multicolumn{2}{|c|}{$\begin{array}{c}\text { LSD } 0.1 \%=84.4 \text { thousand } \\
\mathrm{pl} / \mathrm{ha}\end{array}$} \\
\hline \multirow{3}{*}{2011} & $\mathrm{~V}_{1}$ - Control (untreated) & 290.00 & 100.00 & 0.00 & Control \\
\hline & $\mathrm{V}_{2}-$ Lignohumate $^{*}$ & 294.00 & 101.38 & 4.00 & \\
\hline & $\begin{array}{c}\text { LSD } 5 \%=20.6 \text { thousand } \\
\mathrm{pl} / \mathrm{ha}\end{array}$ & \multicolumn{2}{|c|}{$\begin{array}{c}\text { LSD } 1 \%=32.3 \text { thousand } \\
\mathrm{pl} / \mathrm{ha}\end{array}$} & \multicolumn{2}{|c|}{$\begin{array}{c}\text { LSD } 0.1 \%=55.0 \text { thousand } \\
\mathrm{pl} / \mathrm{ha}\end{array}$} \\
\hline \multirow{3}{*}{2012} & $\mathrm{~V}_{1}$ - Control (untreated) & 229.83 & 100.00 & 0.00 & Control \\
\hline & $\mathrm{V}_{2}-$ Lignohumate $^{*}$ & 236.67 & 102.98 & 6.84 & \\
\hline & $\begin{array}{c}\text { LSD } 5 \%=11.7 \text { thousand } \\
\text { pl } / \text { ha }\end{array}$ & \multicolumn{2}{|c|}{$\begin{array}{c}\text { LSD } 1 \%=18.4 \text { thousand } \\
\mathrm{pl} / \mathrm{ha}\end{array}$} & \multicolumn{2}{|c|}{$\begin{array}{c}\text { LSD } 0.1 \%=31.3 \text { thousand } \\
\mathrm{pl} / \mathrm{ha}\end{array}$} \\
\hline \multirow{3}{*}{$\begin{array}{c}\text { Average } \\
2010- \\
2012\end{array}$} & $\mathrm{~V}_{1}$ - Control (untreated) & 274.17 & 100.00 & 0.00 & Control \\
\hline & $\mathrm{V}_{2}-$ Lignohumate $^{*}$ & 278.33 & 101.52 & 4.16 & \\
\hline & $\begin{array}{c}\text { LSD } 5 \%=11.0 \text { thousand } \\
\text { pl } / \mathrm{ha}\end{array}$ & \multicolumn{2}{|c|}{$\begin{array}{c}\text { LSD } 1 \%=17.2 \text { thousand } \\
\mathrm{pl} / \mathrm{ha}\end{array}$} & \multicolumn{2}{|c|}{$\begin{array}{c}\text { LSD } 0.1 \%=29.3 \text { thousand } \\
\mathrm{pl} / \mathrm{ha}\end{array}$} \\
\hline
\end{tabular}


In all three experimental years between the control and the treated variants there were significant differences. They have fluctuated within narrow limits $(3.7-3.8 \mathrm{~cm})$, which means that the effects of the Lignohumate treatments were used equally in both 2010 and 2011 conditions and in the conditions of 2012, considered less favorable for the soybean crop due to the drought that has been installed since July.

The negative effects of less favorable conditions recorded in 2012 were found to reduce the plant height in both the control and the treated variant. Thus, in 2010 the control plants had a height of $60.5 \mathrm{~cm}$ and $59.9 \mathrm{~cm}$ in 2011; in 2012 the plants had only $47.8 \mathrm{~cm}$. In the fertilized variant the average plant height was $64.2 \mathrm{~cm}$ in 2010, 63.7 $\mathrm{cm}$ in 2011 and only $51.6 \mathrm{~cm}$ in 2012 (Fig. 2).

The climatic conditions influenced more the plant height and less the way how the Lignohumate treatments were used by them, the differences between the control and the treated variants being relatively constant over the three years.

The difference between the treated and the control variants varied during the growing season, being influenced on one hand by the way the Lignohumate was exploited by plants Lignohumate and secondly by the stage at which the treatments were administered (one seed treatment and three vegetation: in the 2-3 leaves stage, before and after flowering). In these circumstances, in the three on

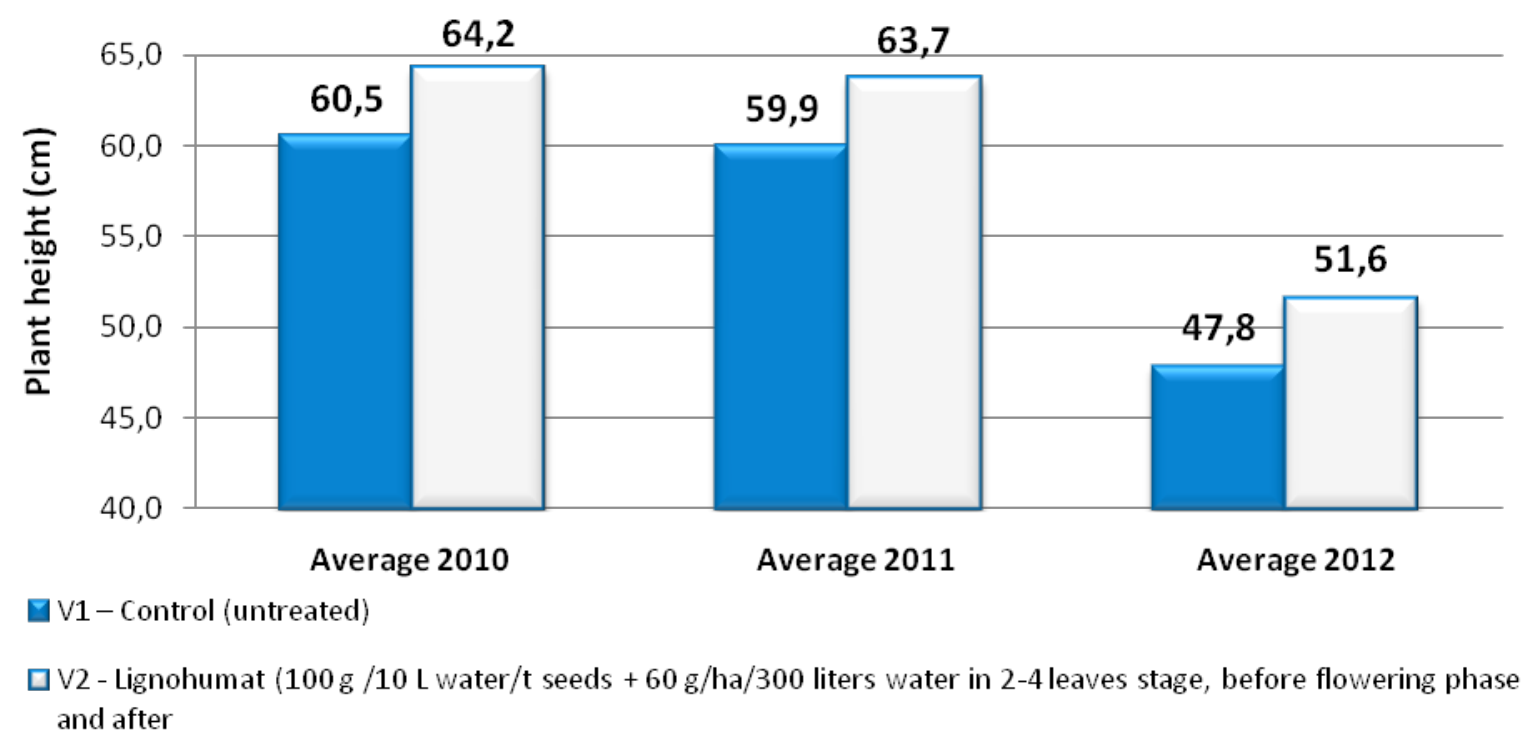

Fig. 2. The average plant height in soybean - average values on growing stages

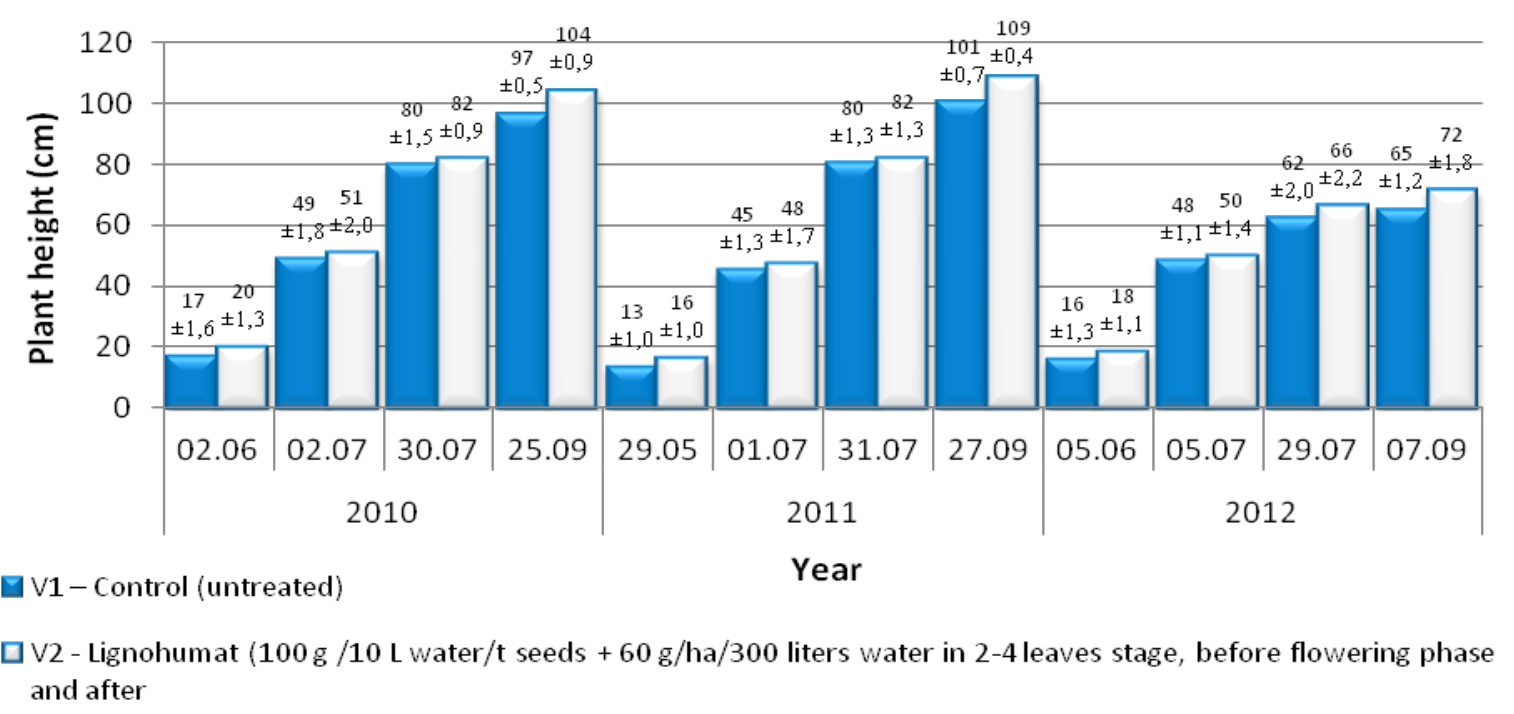

Fig. 3. The influence of Lignohumate on the average plant height in soybean (2010-2012) 
experimental years the difference ranged from $3.2 \mathrm{~cm}$ at about 30 days after sowing and before flowering, from 2 to $4 \mathrm{~cm}$ after flowering and from 7 to 8 at harvest (Fig. 3).

The statistical analysis of the three experimental years data showed that about 30 days after sowing there were registered the highest differences regarding the plant height, for the treated variant being $19.4 \%$ higher than the control, which had an average height of 15.2 cm (Tab. 3). This highlights the fact that the seed treatment is superior to that applied on leaves.

During the vegetation, in early July, there was a slight decrease of the Lignohumate influence on plant height, but the treatments applied before and after flowering have contributed significantly to the differences of $7.4 \mathrm{~cm}(8.5 \%)$ between the variant treated with Lignohumate and the control, where the average plant height was $87.4 \mathrm{~cm}$ (Tab. 3).

The statistical analysis of the average values on years and vegetation stages highlighted a very significant influence of the Lignohumate treatments on the average plant height. Thus, the treated plants recorded a higher plant height (3.7 $\mathrm{cm}$ higher) than the untreated control, which recorded an average plant height of $56.1 \mathrm{~cm}$ (Tab. 4).

Determining the chlorophyll content of the leaves

Chlorophyll content of the leaves was influenced by the Lignohumate treatments, especially in 2012 when, between the treated variant and the control variant was obtained the highest difference (2.7 CCI), statistically assured (Tab. 5).

Tab. 3 The influence of Lignohumate on the average plant height in soybean - average values 20102012

\begin{tabular}{|c|c|c|c|c|c|}
\hline \multirow[b]{2}{*}{$\begin{array}{l}\text { Vegetation } \\
\text { stage }\end{array}$} & \multirow[b]{2}{*}{ Variant } & \multicolumn{2}{|c|}{ Plant height } & \multirow[b]{2}{*}{$\begin{array}{l}\text { Difference } \\
\quad(\mathrm{cm})\end{array}$} & \multirow[b]{2}{*}{ Significance } \\
\hline & & $\mathrm{cm}$ & $\begin{array}{l}\% \text { compared } \\
\text { to control }\end{array}$ & & \\
\hline \multirow{3}{*}{$\begin{array}{c}\text { Emergence } \\
(29.05-05.06)\end{array}$} & $\mathrm{V}_{1}-$ Control (untreated) & 15.2 & 100.0 & 0.0 & Control \\
\hline & $\mathrm{V}_{2}-$ Lignohumate $^{*}$ & 18.2 & 119.4 & 3.0 & $\mathrm{xxx}$ \\
\hline & LSD $5 \%=1.0 \mathrm{~cm}$ & \multicolumn{2}{|c|}{ LSD $1 \%=1.6 \mathrm{~cm}$} & \multicolumn{2}{|c|}{$\mathrm{LSD} 0.1 \%=2.7 \mathrm{~cm}$} \\
\hline \multirow{3}{*}{$\begin{array}{c}\text { Vegetation } \\
(01.07-05.07)\end{array}$} & $\mathrm{V}_{1}-$ Control (untreated) & 47.5 & 100.0 & 0.0 & Control \\
\hline & $\mathrm{V}_{2}-$ Lignohumate $^{*}$ & 49.5 & 104.2 & 2.0 & \\
\hline & LSD $5 \%=2.1 \mathrm{~cm}$ & \multicolumn{2}{|c|}{ LSD $1 \%=3.3 \mathrm{~cm}$} & \multicolumn{2}{|c|}{ LSD $0.1 \%=5.6 \mathrm{~cm}$} \\
\hline \multirow{3}{*}{$\begin{array}{c}\text { Vegetation } \\
(29.07-31.07)\end{array}$} & $\mathrm{V}_{1}-$ Control (untreated) & 74.1 & 100.0 & 0.0 & Control \\
\hline & $\mathrm{V}_{2}-$ Lignohumat $^{*}$ & 76.8 & 103.7 & 2.7 & $\mathrm{xx}$ \\
\hline & LSD $5 \%=1.2 \mathrm{~cm}$ & \multicolumn{2}{|c|}{$\mathrm{LSD} 1 \%=1.9 \mathrm{~cm}$} & \multicolumn{2}{|c|}{ LSD $0.1 \%=3.2 \mathrm{~cm}$} \\
\hline \multirow{3}{*}{$\begin{array}{c}\text { Harvest } \\
(07.09-27.09)\end{array}$} & $\mathrm{V}_{1}-$ Control (untreated) & 87.4 & 100.0 & 0.0 & Control \\
\hline & $\mathrm{V}_{2}-$ Lignohumate $^{*}$ & 94.8 & 108.5 & 7.4 & $\mathrm{xxx}$ \\
\hline & LSD $5 \%=1.1 \mathrm{~cm}$ & \multicolumn{2}{|c|}{ LSD $1 \%=1.8 \mathrm{~cm}$} & \multicolumn{2}{|c|}{ LSD $0.1 \%=3.0 \mathrm{~cm}$} \\
\hline
\end{tabular}

Tab. 4. The influence of Lignohumate on the average plant height in soybean

\begin{tabular}{|c|c|c|c|c|}
\hline \multirow[b]{2}{*}{ Variant } & \multicolumn{2}{|c|}{ Plant height } & \multirow[b]{2}{*}{$\begin{array}{l}\text { Difference } \\
(\mathrm{cm})\end{array}$} & \multirow[b]{2}{*}{ Significance } \\
\hline & $\mathrm{cm}$ & $\begin{array}{c}\% \text { compared to } \\
\text { control }\end{array}$ & & \\
\hline $\mathrm{V}_{1}$ - Control (untreated) & 56.1 & 100.0. & 0.0 & Control \\
\hline $\mathrm{V}_{2}$ - Lignohumate ${ }^{*}$ & 59.8 & 106.60 & 3.7 & $\mathrm{xxx}$ \\
\hline LSD $5 \%=0.6 \mathrm{~cm}$ & \multicolumn{2}{|c|}{ LSD $1 \%=1.0 \mathrm{~cm}$} & \multicolumn{2}{|c|}{ LSD $0.1 \%=1.7 \mathrm{~cm}$} \\
\hline
\end{tabular}


The climatic conditions have influenced the way in which the Lignohumate was asserted by plants, under a favorable year for soybean, such as 2011, recording the lowest difference between the treated and the control variants, of only 1.1 CCI. Under the conditions of stress, as occurred in 2012, for the treated variant the leaf chlorophyll content was 25.6 CCI, while for the control was 22.9 CCI (Tab. 5).
Depending on the level on which the determination has been made, the chlorophyll content of the leaves varied, being lower in the upper third of the plant, and higher in the median floor thereof.

The chlorophyll content of the leaves aried per plant depending on the climatic conditions. Thus, in normal climatic conditions, as occurred in 2010 and 2011, the differences between the

Tab. 5. The influence of Lignohumate on the chlorophyll content of soybean leaves (average values per plant)

\begin{tabular}{|c|c|c|c|c|c|}
\hline \multirow[b]{2}{*}{ Year } & \multirow[b]{2}{*}{ Variant } & \multicolumn{2}{|c|}{ Chlorophyll } & \multirow{2}{*}{$\begin{array}{l}\text { Difference } \\
\quad \text { (CCI) }\end{array}$} & \multirow[b]{2}{*}{ Significance } \\
\hline & & CCI & $\begin{array}{c}\% \text { compared to } \\
\text { control }\end{array}$ & & \\
\hline \multirow{3}{*}{2010} & $\mathrm{~V}_{1}$ - Control (untreated) & 26.7 & 100.00 & 0,0 & Control \\
\hline & $\mathrm{V}_{2}$ - Lignohumate ${ }^{*}$ & 28.1 & 105.24 & 1,4 & \\
\hline & LSD $5 \%=1.6 \mathrm{CCI}$ & \multicolumn{2}{|c|}{ LSD $1 \%=2.6 \mathrm{CCI}$} & \multicolumn{2}{|c|}{ LSD $0.1 \%=4.4 \mathrm{CCI}$} \\
\hline \multirow{3}{*}{2011} & $\mathrm{~V}_{1}$ - Control (untreated) & 25.0 & 100.00 & 0.0 & Control \\
\hline & $\mathrm{V}_{2}-$ Lignohumate $^{*}$ & 26.1 & 104.40 & 1.1 & \\
\hline & LSD $5 \%=1.6 \mathrm{CCI}$ & \multicolumn{2}{|c|}{ LSD $1 \%=2.5 \mathrm{CCI}$} & \multicolumn{2}{|c|}{ LSD $0.1 \%=4.3 \mathrm{CCI}$} \\
\hline \multirow{3}{*}{2012} & $\mathrm{~V}_{1}$ - Control (untreated) & 22.9 & 100.00 & 0.0 & Control \\
\hline & $\mathrm{V}_{2}-$ Lignohumate $^{*}$ & 25.6 & 111.79 & 2.7 & $\mathrm{xxx}$ \\
\hline & LSD $5 \%=0.6 \mathrm{CCI}$ & \multicolumn{2}{|c|}{ LSD $1 \%=1.0 \mathrm{CCI}$} & \multicolumn{2}{|c|}{ LSD $0.1 \%=1.7 \mathrm{CCI}$} \\
\hline \multirow{3}{*}{$\begin{array}{c}\text { Average } \\
2010-2012\end{array}$} & $\mathrm{~V}_{1}$ - Control (untreated) & 24.9 & 100.00 & 0.0 & Control \\
\hline & $\mathrm{V}_{2}$ - Lignohumate ${ }^{*}$ & 26.6 & 106.83 & 1.7 & $\mathrm{x}$ \\
\hline & $\frac{\text { LSD } 5 \%=1.1 \mathrm{CCI}}{100 \mathrm{~g} / 10 \mathrm{~L} \text { water } / \mathrm{t} \text { seeds }}$ & \multicolumn{2}{|c|}{ LSD $1 \%=1.7 \mathrm{CCI}$} & \multicolumn{2}{|c|}{ LSD $0.1 \%=3.0 \mathrm{CCI}$} \\
\hline
\end{tabular}

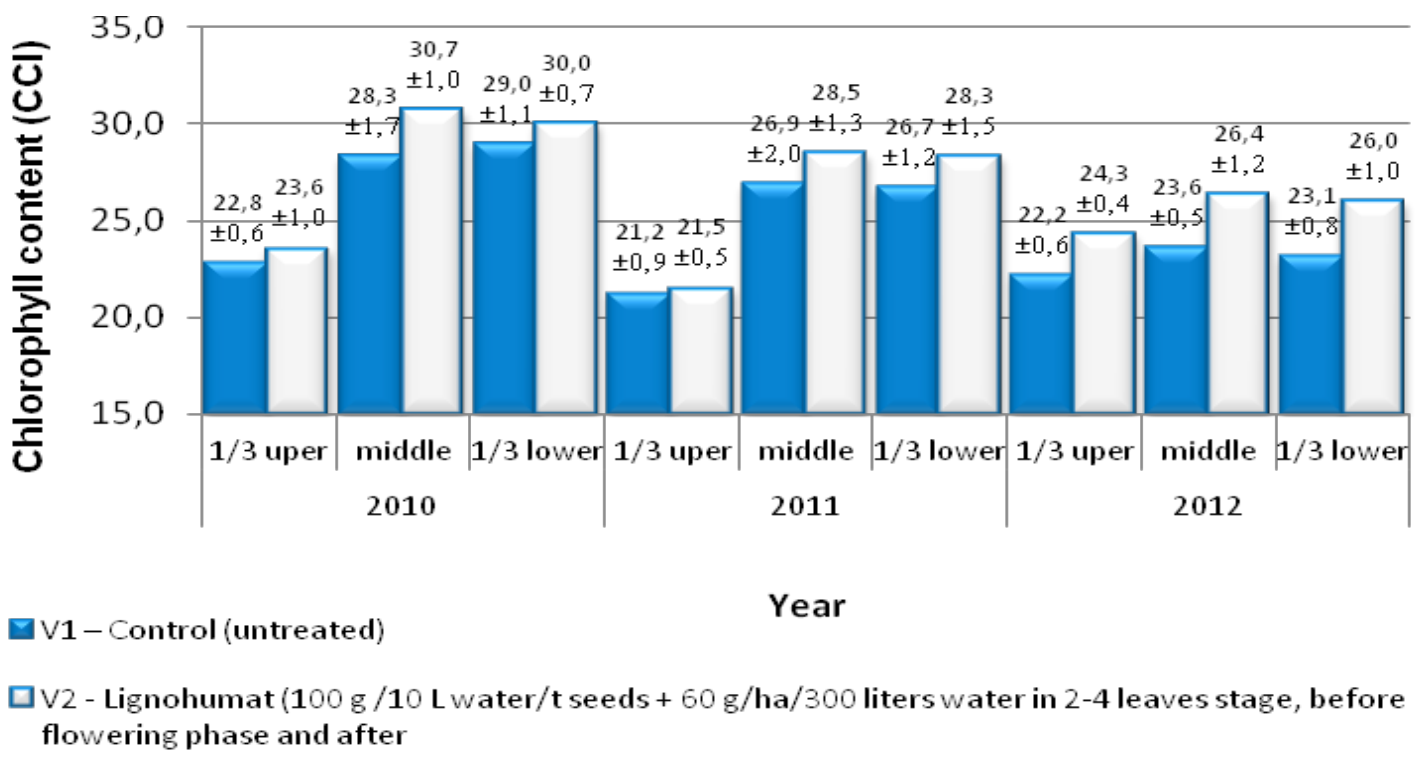

Fig. 4. The chlorophyll content of soybean leaves (average values on growing stages) 
treated and the control variants ranged from 0.8 to $0.3 \mathrm{CCI}$ in the upper third of the plant, $2.4-1.6$ CCI in its middle level and between 1.0-1.6 CCI in the lower third (Fig. 4). The trend continued in 2012, when between the treated and the control variants, the differences were higher compared to 2010 and 2011, of 2.1 CCI in the upper third of the plant, $2.8 \mathrm{CCI}$ in the median level and $2.9 \mathrm{CCI}$ in the lower level (Fig. 4).

These results highlight that the Lignohumate treatments are designed to reduce the negative effects of stress on plants, for 2012 being a water stress, especially starting with July.

Our results confirm the data from the literature Eladia M. Pena-Mendez et al., (2005), Eyheraguibel B., et al. (2008), Oleg Gladkov, Rodion Poloskin, (2010)) and from previous researches Galeș D.C., Jităreanu G., (2014), which showed that the humic substances are efficient in the plant growth and development and have an indirect influence on some morpho-physiological factors by increasing the soil fertility. Eyheraguibel B. et al., (2008), showed that the humic substances don't increase the percent or ratio of seed germination, but increase the root elongation, due to the water and mineral consumption increase of the treated plants.

\section{CONCLUSION}

The humic fertilizer Lignohumate positively influenced the average number of pods per plant, average plant height and chlorophyll content of leaves. Thus, we can say that for the soybean crop, it has prospects of being successfully used, by being introduced in the classical crop technology.

The prospect for this fertilizer is to be tested for other crops too, possibly in a conservative tillage system.

Acknowledgment: This paper was published under the frame of European Social Fund, Human Resources Development Operational Programme 2007-2013, project no. POSDRU/159/1.5/ S/132765.

\section{REFERENCES}

1. Chen Y, Senesi N, Schnizer M (1977). Information provided on humic substances by E4/E6 ratios. Soil Sci. Soc. Am. J. 41, 352-358, ISSN 0361-5995.

2. Eyheraguibel B, Silvestre J, Morard P (2008). Effects of humic substances derived from organic waste enhancement on the growth and mineral nutrition of maize. Bioresource Technology, 99, 4206-4212, ISSN 0960-8524.

3. Eladia MPM, Havel J, Patočka J (2005). Humic substances - compounds of still unknown structure: applications in agriculture, industry, environment, and biomedicine. J. Appl. Biomed. 3: 13:24, ISSN 1214-0287.

4. Forth HD, Turk LM (1972). Fundamentals of soil science $5^{\text {th }}$ edition, ISBN 0-471-26790-2.

5. Galeș DC, Jităreanu G (2014). The influence of humic fertilizer on morphological and physiological properties of maize crop, in the conditions of the Moldavian Plateau. Lucrări Ştiințifice - vol. 57, seria Agronomie.

6. Klučáková M, Pekař M, (2006). New model for equilibrium sorption of metal ions on solid humic acids. Colloids Surf., A Physicochem. Eng. Asp. 286 (1-3), 26-133.

7. Klučáková M, Pekař M, (2005). Physical and chemical kinetics in humic dispersions. In: Ghabbour EA, Davies G (Eds.), Humic Substances: Molecular Details and Applications in Land and Water Conservation. InTaylor \& Francis, New York, pp. 167-188.

8. Klučáková M, Pekař M (2004). Study of diffusion of metal cations in humic gels. In: Ghabbour, E.A., Davies, G. (Eds.), Humic Substances: Nature's Most Versatile Materials. InTaylor \& Francis, New York, pp. 263-274.

9. Klučáková M, Pekař M (2003b). Study of structure and properties of humic and fulvic acids. IV. Study of interactions of $\mathrm{Cu}^{2+}$ ions with humic gels and final comparison. J. Polym. Mater. 20, 155-162. ISSN 0970-0838.

10. Klučáková M, Pekař M (2003a). Study of structure and properties of humic and fulvic acids. III. Study of complexation of $\mathrm{Cu}^{2+}$ ions with humic acid in sols. J. Polym. Mater. 20, 145-154. ISSN 0970-0838.

11. Klučáková M (2002). Study of structure and properties of humic and fulvic acids. II: Study of adsorption of $\mathrm{Cu}^{2+}$ ions to humic acids extracted from lignite. J. Polym. Mater 19, 287-294. ISSN 0970-0838.

12. Klučáková M (2000). Structure and properties of humic and fulvic acids. I. Properties and reactivity of humic and fulvic acids. J. Polym. Mater. 17, 337-356. ISSN 0970-0838.

13. Morard P, Gourdon C, Rigal L, Prat L, Silvestre J (2005). Procédé de de préparation d'une composition humique artificielle et application. French Patent.

14. Oleg G, Rodion P (2010). Efficiency and Application Prospects of Humatized Mineral Fertilizers, 15th Meeting of the International Humic Substances Society Tenerife Canary Islands. June 27- July 2.

15. Stefan M (2008). Biologia microorganismelor rizosferice aplicații biotehnologice, Ed. Tehnopress Iași, p. 369, ISBN 973-702-597-5.

16. Topa D, Jitareanu G, Ailincai C, Raus L (2013). Impactul unor sisteme minime asupra productiei si fertilitatii solului. Ed. Ion Ionescu de la Brad - Iasi, ISBN 978-973147-122-8.

17. Tugarinov LV, Alexeyeva SV, Skrenzhevsky SS (2010). Lignohumate in Field Husbandry: Scope of Application (http://www.amagro.cz/content/file/Lignohumate NPO. pdf). 